\title{
IS YOUTH UNEMPLOYMENT IN EU COUNTRIES STRUCTURAL?
}

\section{Dr. Darka Podmenik}

Institute for developmental and strategic analysis, Slovenia

E-mail: darka.podmenik@guest.arnes.si

\section{Maruša Gorišek}

Institute for developmental and strategic analysis, Slovenia

E-mail: marusa.gorisek@gmail.com

\begin{abstract}
This paper's main aim is to observe and confirm youth unemployment as a structural phenomenon in certain EU countries, including Slovenia. An innovative contribution is that it complements the prevailing economistic discourse with a sociological one. In the introduction, a brief history and overview of youth unemployment is presented. Slovenia is only briefly mentioned as having one of the relatively longest-lasting youth unemployment rates in the EU. In sections 2 and 3, approaches from economics and sociology are relied on while discussing three 'types' of EU countries with regard to different structural unemployment rates. From a sociological view, the longterm nature of youth unemployment is described, together with its impact on the social structure and (possible) socially destructive and economically destabilizing consequences. In section 4, analysis of "every-day life" indicators, namely, young people's perceptions of work and life, reveals some surprising facts that depart from previous findings. In short: young people are more satisfied with their work and lives than older generations.
\end{abstract}

Key words: youth (un)employment, structural unemployment, (youth) labor market(s), employers, economistic approaches and indicators, sociological approaches and indicators, EU member countries, Slovenia, young first jobseekers; opinions and values of young generation 


\section{Introduction}

Ever since the "oil crises" of the 1970s, labor markets have not recovered in many European countries, with the average EU unemployment rate persistently increasing to reach a peak in the 1990s (Podmenik and Ivančič 2017). Data (OECD 1977; OECD 1994) for that period show that the rapid technological, economic, and employment shifts for higher educational and vocational levels of the labor force were not accompanied by an expansion in the number of adequate workplaces (OECD 1994; Hannan and Werquin 2001, 101). At the same time, certain authors assess that a surplus of some $30 \%$ of over-educated youth came into being and started to be marginalized (Coleman 1991; Sprangers 1992; Teichler 2000). It has been shown that the average youth unemployment rate has not dropped since the mid 1990s compared to the general unemployment rate (Noelke and Mueller 2011; Leuven and Oosterbeek 2011 in Podmenik and Ivančič 2017, 187).

Between 1995 and 2000, over 60\% of all newly created jobs in Europe were found in knowledge-intensive and technologically demanding sectors and those requiring higher cognitive skills (Greenwood and Stuart 2003). The creation of "net" jobs in the EU has been shown to be lagging behind the increase in the active population, as clearly revealed by unemployment rates for particular social groups, women, immigrants, the elderly and especially young people seeking their first job (ibid.). Labor market research studies highlight significant changes in these areas (Brauns, Gangl, and Scherer 2001). (Youth) labor markets started to become more flexible and fluid in developed and transition countries.

At the turn of the millennium, the development of highly innovative and creative knowledge and knowledge-based economies was ever more strongly seen as the "key" to opening the door to competitiveness, employability, and social inclusion (following Becker 1962). Yet, at the same time, it was observed that education and knowledge, recognized as two crucial factors for developing knowledge-based societies (Bell 1974; Stehr 2005), were being hindered in exercising this function. The role of knowledge and education in solving socio-economic problems has decreased, while more and more national economies seem unable to fully utilize their current human resources. Even during the 1970s, American researchers warned of the problem of over-education, namely, that the number of highly educated young people would exceed the demand for them in labor markets. They compared the USA and the EU and suggested the problem of over-education might be more considerable for EU states due to the wider and larger state investments made in education and the thereby limited freedom of labor markets (Leuven and Oosterbeek 2011, v Podmenik and Ivančič 2017). The massification of 
higher education, which has not been accompanied by an increased number of workplaces, led to some $30 \%$ of young people being over-educated at the start of the millennium. However, this obvious trend did not see a reduction in private and public investments for achieving the highest levels of education (Wolbers 2003).

Goldthorpe (1996) highlights the fact that comparative empirical data offer little basis for the claim that firms and enterprises in modern societies chiefly rely on formal qualifications obtained from the education system as a typical form of worker selection. Other authors state that as the general education level rises the information value of higher levels of education decreases (Freeman 1976; Jonsson 1987). Employers might also downplay the importance of educational qualifications by choosing individuals they trust or know personally. Goldthorpe $(1996,276)$ and Coleman $(1988)$ stress that in the eyes of management merit is often conceived through attitudinal and behavioural attributes, aspects that bear little relation to education. In advanced post-industrial enterprises, workers' selection of a wide range of positions is guided by more or less elaborate techniques of personality and lifestyle assessment mainly aimed at identifying qualities such as loyalty, commitment, adaptability, capacity for teamwork and the like. Employers may thus intensify their selection processes in the case of more demanding positions.

Despite findings showing that the economic stability in the first half of 2010 was reflected in the labor markets of 27 EU countries in lower unemployment, the 2008 economic crisis still affected over half the EU member states, which were then in recession or on the path to it (Singh 2010, 29). Labor markets became too fluid and flexible and were unable to cope with the growing demand and supply pressures. Moreover, in many EU countries while the demands of employers had grown to such an extent that some national employment legislation had been amended to them. At the same time, part-time and other "insecure jobs" were actively being promoted in the EU as a way of increasing employment rates to meet the Lisbon Strategy's employment goals (Lesche and Watt 2011). These new "precarious" employment forms have led to lower wages, reduced social security, and a lack of career opportunities, social stress, lower fertility, brain drain, and certain other collective and personal distractions. However, while adapting national labor laws to employers' requirements various forms of unlawful employment went unpunished. So-called non-normal employment 
(Boltanski and Chiapello 2007) ${ }^{1}$ has become widespread in many EU countries, especially for marginalized groups, including young first jobseekers.

Like other European countries, Slovenia has seen considerable improvement in the educational attainment of its population in the last 20 years, especially among younger generations. Slovenia's education system, labor market, and employment policy underwent major changes and challenges in the transition from the former socialist system to a capitalist one. Slovenia may be characterized (with regard to other transitional countries) by its relatively high investment in education and relatively high education levels of the population, ${ }^{2}$ yet the education system is rigid and a significant disproportion exists between professional/vocational secondary and tertiary study programs and non-vocational ones in favor of the latter (Podmenik and Ivančič 2017, 192). In the employment area, the Slovenian labor market was quite rigid compared with other transition countries up until 2002 when amended labor legislation loosened up the protection of employees and enabled a wide range of uncertain forms of employment. The labor market has since gradually become more flexible and deregulated, while employers have achieved greater independence and influence. Employers' greater freedom has led to the gradual yet intense introduction of various forms of atypical employment, especially for young first-time jobseekers. In 2018, the part-time employment of young Slovenians (15-29 years) was above the average in the EU (34\% in Slovenia; EU average of 32\%). There is a bigger difference in temporary contracts; $62 \%$ young people were working under such contracts in Slovenia in 2018, although the EU average was $41 \%$ (Eurostat 2020). The altered relationships between young jobseekers and job providers are also changing young people's attitudes to work. One Slovenian author (Dragoš 2020) notes that the share of Slovenian youth (20-24 years) holding at least a high school education has exceeded the European average for years. At the same time, the share of young people (15-29 years) afraid of becoming unemployed doubled between 2000 and 2018. In 2000, 53\% of

\footnotetext{
${ }^{1}$ In an extensive analysis of unemployment in France, the authors introduce the notion of non-normal employment for all those new, inventive types of employment, which in many different ways violate the national labor legislation. As a side note, they could be called illegal, but legitimate in terms of unsanctioned occurrence (which is different across EU countries, of course).

${ }^{2}$ In 2017, total public expenditure on education was $4.49 \%$ of GDP, while the EU average was 4.7\% (UMAR 2019, Eurostat 2019).
} 
young Slovenians were not afraid of becoming unemployed, whereas in 2018 this share was just 19.2\% (Klanjšek and Kobše 2019 in: Dragoš 2020, 2).

\section{Economic Indicators of Structural Youth Unemployment}

Structural unemployment is generally defined using economists' terms and indicators. Here it is seen as the mismatch between the supply of labor in terms of workforce skills and the demand for labor in terms of employers' skill requirements (Valletta and Kuang 2010). Its chief characteristic is lacking work for a longer period of time due to the shifts in the economy, producing the marginalization of certain workers and their jobs. In modern economies, such shifts are mostly triggered by the introduction of new technologies. Structural unemployment is accompanied by several negative processes like: the growing migration of well-paid jobs to those with lower personal costs; temporary employments with little chance of promotion to long-term ones; the lack of job flexibility; low work mobility and deficient opportunities for acquiring the new tasks and skills (ibid.). Structural unemployment is long lasting because it is influenced by more than one business cycle. It is also expanding since work mismatches in one industry can overwhelm the entire employment system. Moving workers from old jobs to new jobs is very costly in economic and social terms (What is "structural unemployment?" 2019). Structural unemployment often hurts certain regions more than others and forces local people to move away to find new opportunities in other regions, even abroad. Migration, regardless of destination, leaves disrupted communities behind. (ibid.)

Structural unemployment is also the subject of an entire field of macroeconomic research on the relationships among macroeconomic conditions like inflation and income distribution (Mocan, 1999). In this framework, structural unemployment is exposed as a factor of social stratification. One author states that the increase in structural unemployment increases the income share of the highest quintile, and decreases the shares of the bottom sixty percent of the population (ibid., 32).

All of the economists dealing with structural unemployment mentioned above also included social parameters, even though indicators and measures of structural unemployment are purely economistic. As one critical author notes, policymakers and economists have largely been focused on the relationship between unemployment and job vacancy rates, meanwhile in the case of the long run additional actors and social circumstances must be taken into account (Valletta and Kuang 2010,1). If structural unemployment is actually rising or its duration is beyond the medium term (from 1 to 2 years), 
it cannot be eased by conventional monetary and fiscal policy and becomes a dilemma for policymakers. Economic studies of structural unemployment typically focus on the average working population and thereby leave out young people as a specific population of interest. Still, this brief overview of the economist's view of structural unemployment reveals the subject's complexity and how it intertwines with social, institutional, and political phenomena.

The most commonly used measures in economist comparisons of structural unemployment (in inter/national or segmented labor markets) is the structural unemployment index (the ratio between job vacancies and the number of unemployed). To present the long-term trend, EU databases were analyzed, although unfortunately the data were missing for several EU members.

Figure 1: Comparison of the average job vacancy rate and youth unemployment rate (15-29 years) in the EU, 2008-2018

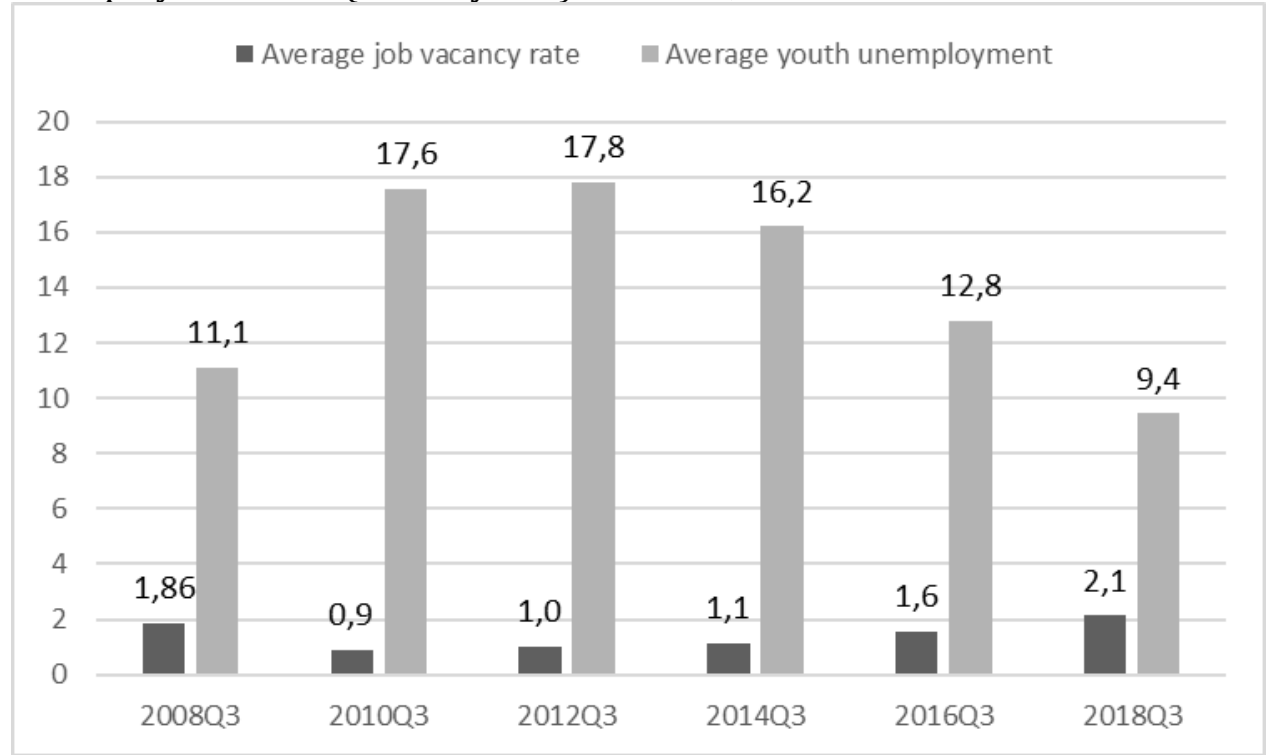

Source: Eurostat database 2020

The long-term data in Figure 1 show, as expected, that average job vacancy rates declined in the EU during the crisis; they recovered after it and were higher than the pre-crisis state in 2018. Also expected, the average youth unemployment rate rose during the crisis and fell between 2012 and 2018 below the level for 2008. Both of these trends were predictable, whereas the 
economic growth and rise in social conditions have led to greater employment, including for young jobseekers. However, the way the job vacancy and unemployment rates have been reconciled during and after the economic crises is not so clear and typical of all EU members.

The structural youth unemployment movement may be described as very diverse; from the Netherlands with a very moderate increase in the post-crisis period to Portugal with the highest youth unemployment and lowest job vacancy rates. Examples of countries with the highest, namely over $20 \%$, postcrisis unemployment and the least jobs available (around 1\%) also include Latvia, Slovakia, and Estonia. Yet, in the case of Estonia, the post-crisis unemployment was rapidly eased, whereas in the other two cases this took nearly a decade (see the data in Figure 2). A striking example is Slovenia where the youth unemployment rate has not reached $20 \%$ since the crisis, but has a low rate of vacancies and where the rates were aligned in 2018. All of the other examples shown, except for Finland, see a significant rise in youth unemployment immediately after the crisis, which also falls relatively quickly and is matched by a rise to pre-crisis vacancy levels.

In order to make the comparisons more transparent, we created a composite index comprising the youth unemployment (YUR) and job vacancy (JVR) rate (Index $=$ YUR/JVR). For all selected countries, the data presented in the Figure 2 show that youth structural unemployment has not decreased in the 10 years since the crisis, but only returned to the pre-crisis state. 
Figure 2: Structural youth unemployment trend in selected EU countries (for which long-term data are available), 2008-2018, \%, Comparison of the Job Vacancy Rate ${ }^{3}$ (JVR) and Youth Unemployment Rate ${ }^{4}$ (YUR) in Index= YUR/JVR

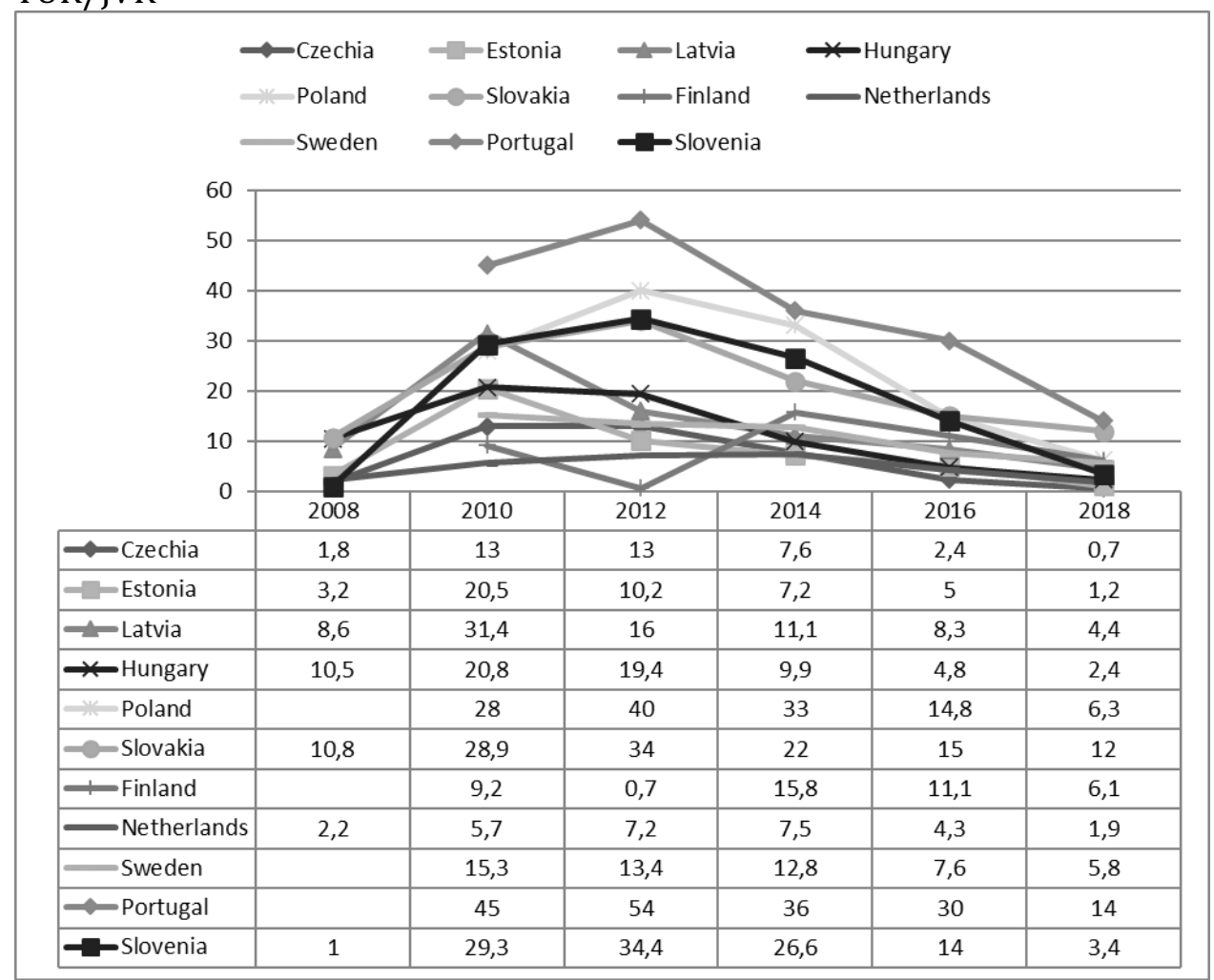

Source: Eurostat database 2020

This index could only be prepared for those countries for which data was available. The graph shows that the ratio between youth unemployment and the job vacancy rate is very similar in 2018 to what it was 10 years before. This reveals that even in times of economic growth youth unemployment persists. There are some positive exceptions like the Czech Republic where

${ }^{3}$ The job vacancy rate (JVR) is the number of job vacancies expressed as a percentage of the sum of the number of occupied posts and the number of job vacancies.

${ }^{4}$ The unemployment rate (YU) is the number of unemployed persons as a percentage of the economically active population (the total number of people employed and unemployed $=$ the labor force) based on the International Labor Office (ILO) definition. 
data for 2018 show a surplus of job vacancies compared to the youth unemployment rate for the first time in the previous 10 years. A significant drop in the ratio between the youth unemployment rate and the job vacancy rate is also seen in Hungary (Index 2008=10.5; 2018=2.4) and Latvia $(2008=8.6 ; 2018=4.4)$. The opposite is revealed in Slovenia $(2008=1$; $2018=3.4$ ) where data show that the surplus of unemployed youth compared to the job vacancy rate is bigger in 2018 than it was in 2008. We may observe that other countries arrived at the same rate after the turbulent decade in between. Sweden and the Netherlands show small movements in the ratio, indicating quite a stable economy. In the Czech Republic, Estonia, Hungary, Latvia, and Slovenia, big cleavages appeared between the youth unemployment rate and job vacancy rate, which may be an indication of less stable economic growth.

\subsection{Duration of the Youth Unemployment as an Indicator of its Structural Significance}

The long-lasting trend of the youth unemployment rate indicates (youth) unemployment crisis and in certain circumstances as well the social one. On one hand, it points to dysfunctions in certain social segments (educational, employment policy, etc.) while, on the other, it exacerbates social dysfunctions (family lives, birth rate, implementation of knowledge, etc.). As such, economists and sociologists use it as a measure of structural unemployment. Its measurement is also non-demanding and has been regularly conducted by countries around the world for a long time, enabling comparisons of different national countries as an advantage. ${ }^{5}$

When looking at the long-term data on the unemployment of youth (aged 15 to 29 years) some clusters are revealed across EU countries: a generally high long-term rate is mostly found in Eastern and Southern European countries, and from the northern ones in Finland and Sweden before the 2008 crisis. Most of these countries have significantly reduced their youth unemployment levels in the post-crisis years, except for Portugal, Romania, and Sweden. Countries with low long-term young unemployment rates are Denmark, Germany, Luxembourg, and the Netherlands. Slovenia stands out for its noticeable fluctuations in youth unemployment; it is low both before and during the crisis, only to increase significantly by 2012 and decline rapidly by 2018 . Hungary, Slovakia, the Czech Republic, and Croatia reveal a

\footnotetext{
${ }^{5}$ Documented in the EUROSTAT database, it continues to contain some insufficiencies and does not allow a precise comparison of all EU countries, although it can still be used for descriptive purposes.
} 
similar trend. According to their long-term youth unemployment rates, EU countries (for which such long-term data were available) are placed in three main groups: Northern/Western, Southern, and Eastern. Shown by groups of countries, these data are presented in Figures 3/1, 3/2, and 3/3.6

Figure 3/1: Youth unemployment (15-29 years), unemployment rates (in \%), 1996-2018, six Northern and Western EU countries

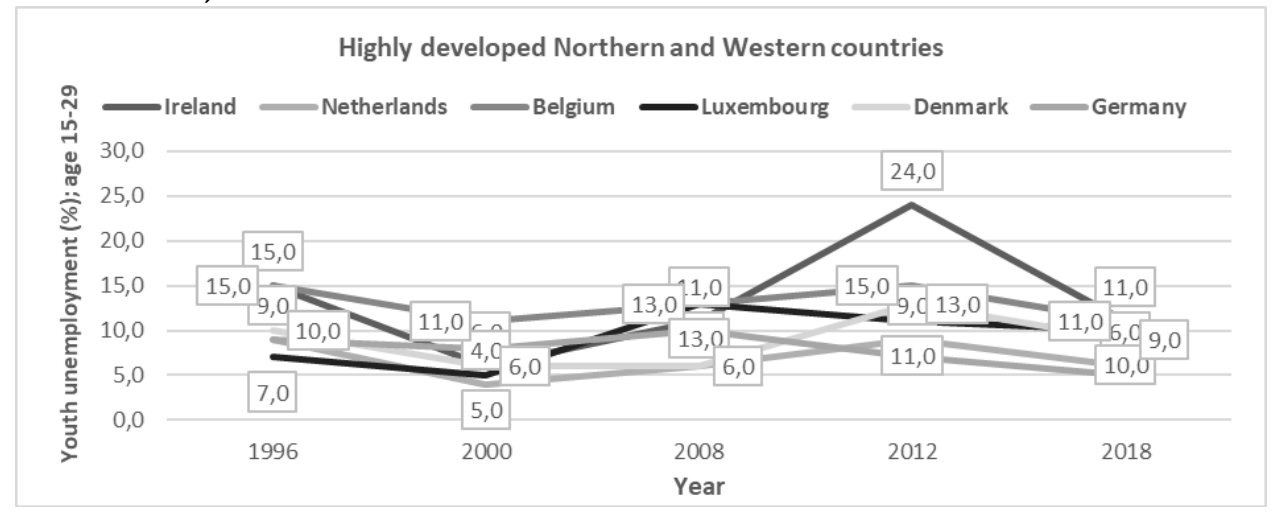

${ }^{6}$ The fourth year student of the Faculty of Social Sciences, University of Ljubljana, Maša Gomilar participated in collecting this data. 
Figure 3/2: Youth unemployment (15-29 years), unemployment rates (in \%), 1996-2018, southern EU countries

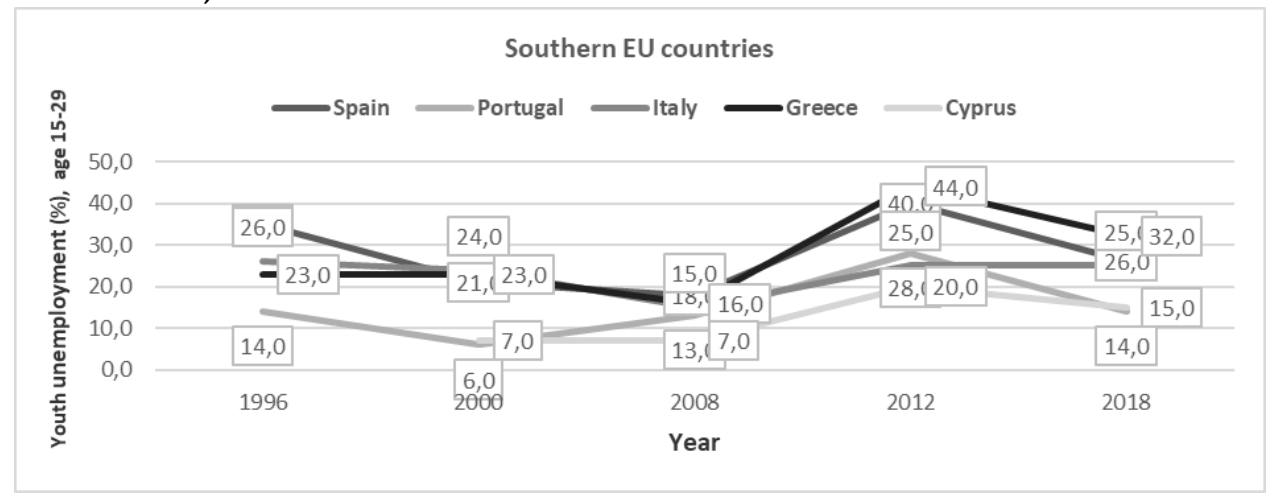

In the first group, the average youth unemployment rate was $10 \%$ in 1996 , $18 \%$ in 2018; in the second group 21\% in 1996 and 22\% in 2018. Differences between these two groups are not only visible in the extent of unemployment; in the developed countries the unemployment rate is half that in the southern ones, but also in the degree of adaptability shown by the unemployed to economic trends. Namely in countries of the first group, unemployment rates were rising in the crisis periods and falling during times of economic recovery (except for Ireland), while rates in the second group show a fall in unemployment during the "2008 crisis" and a rise during the post-crisis recovery that continues today. An exception among Western European countries is France with its structurally high and non-adaptable youth unemployment rate $(21 \%$ in $1996,16 \%$ in $2000,13 \%$ in $2008,18 \%$ in 2012 , and $17 \%$ in 2018) which, according to this indicator, may be classified in the group of Southern countries. 
Figure 3/3: Youth unemployment (15-29 years), unemployment rates (in \%), 1996-2018, Eastern EU countries

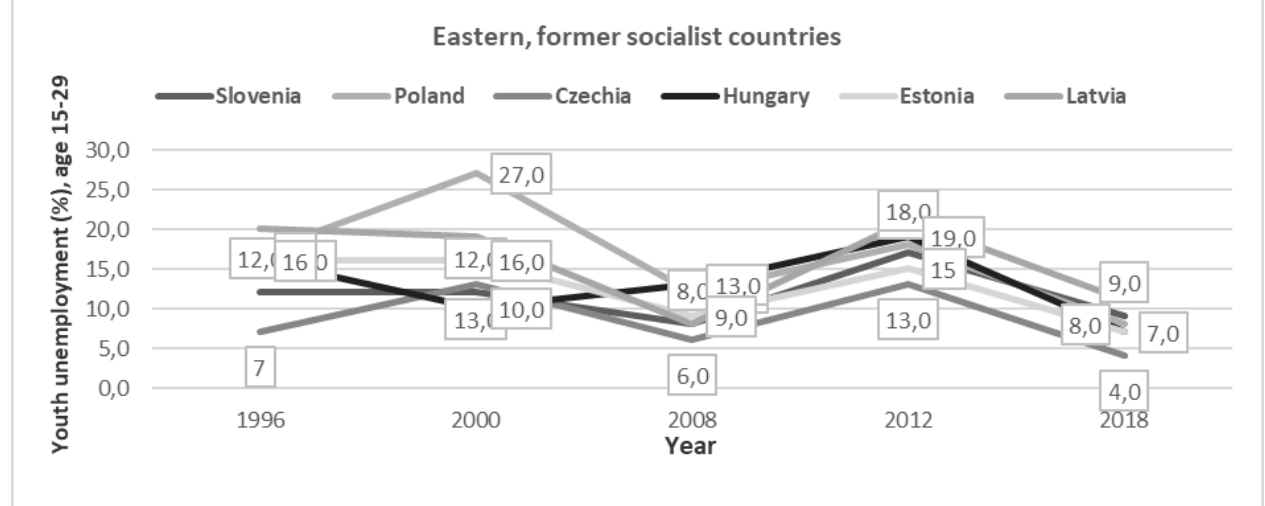

Source: Eurostat database 2020

Data for the third group Eastern, former socialist countries reveal significant deviations from the structural unemployment criteria: youth unemployment rates were considerably reduced in the last two decades, from the general rate of $15 \%$ in 1996 to $8 \%$ in 2018. Moreover, the rates did not follow the national economic trends and were the lowest solely in the period of the "2008 crisis."

Comparing the three groups of EU countries also shows significant differences in youth unemployment at the end (2018) of the long-term period under analysis; in the first two groups (Northern \& Western and Southern), it was on average on the same level as at the beginning in 1996; while in the third group (Eastern, post-transitional) it was lower than in 1996. This information calls for serious reflection on what has been happening to the young unemployed people in these countries. It questions the hypothesis that structural youth unemployment is especially characteristic for these countries and opens up some fresh issues, like why in the last ten years the rates in the Eastern European group have deviated so greatly from the EU average.

Looking at Slovenia as an example of this group, it is seen that the health of the national economy has played at least some role in the lower youth unemployment rate over the last few years. While GDP growth in 2019 was similar to the level in 2004, 20,000 more companies were registered in 2019 than in 2004 and the number of job vacancies in 2019 is considerably higher as is GDP per capita (SURS 2020). 
To what extent this deviation can also be attributed to other reasons, such as the migration of youth labor; the active youth employment policies introduced by the EU; changes in data-gathering rules; national statistical adaptations to the EU's guidelines; or other, more nation-specific features, remains open for future analysis. Regardless of youth unemployment rates having dropped in the last few years in the EU, they continue to be much higher than the general average unemployment rates in the EU.

\section{Sociological Definition of (Youth) Structural Unemployment}

As mentioned in an earlier section, several authors claim that structural unemployment's broader socio-political implications must be addressed interdisciplinary. This is especially true of the young people whose long-term unemployment and/or inadequate employment has gradually become generally acceptable.

In this context, it is worth drawing attention to the non-economic, social, community, and individual characteristics of the youth unemployment crises, unfolding more or less frequently or intensively occurring in many EU countries. Following the definitions, besides the indicators that intertwine with the economic ones (long-lasting unemployment, under-skilled workforce; educational mismatch) there are others which play an important role in and leave behind consequences that are difficult to repair. Namely, all insecure forms of employment have deep and irreparable impacts on the social stability and well-being of young people. Employers' growing requirements for extra competencies creates considerable pressure for firsttime jobseekers. Some data shows the great majority of EU students complete study programs that were "theoretically based" (Education and Culture DG, 2007) and do not meet the altered conditions in the labor markets. Some experts argue that any job is better than unemployment, while others assume that insecure employment forms like temping, occasional, project, and parttime work are inappropriate substitutes for unemployment. Namely, they fail to offer opportunities for social stability, establishing a family, developing roots in the local and professional environment, personal career-building with professional satisfaction and, finally, for facilitating the flow of knowledge from young holders into production, society, and the economy. In social terms, these young resources are lost; moreover, from economic and financial points of view, huge investments in education and training are being lost. It may be expected that such discrepancies cause professional and personal dissatisfaction, which in the long term will manifest as various forms 
of personal and micro-social crises (personal depression which may affects entire families, , a "no child lifestyle", drop of natality rate, etc.).

\subsection{Effects of Structural Unemployment on Social (Sub)Systems}

Considering society as being made up of sub-systems, (Parsons 1977) makes it possible to overlook the structural obstructions that may occur due to wrongly anticipated relationships between the education, employment, and (youth) labor markets. ${ }^{7}$ Individuals as the smallest entities in systems, in our case unemployed youth, are not only connected with each other but with different communities and associations, various institutions, and society as a whole with a certain type and level of mutual solidarity.

Figure 4: Long-term youth (un)employment's interconnectedness with social sub-systems

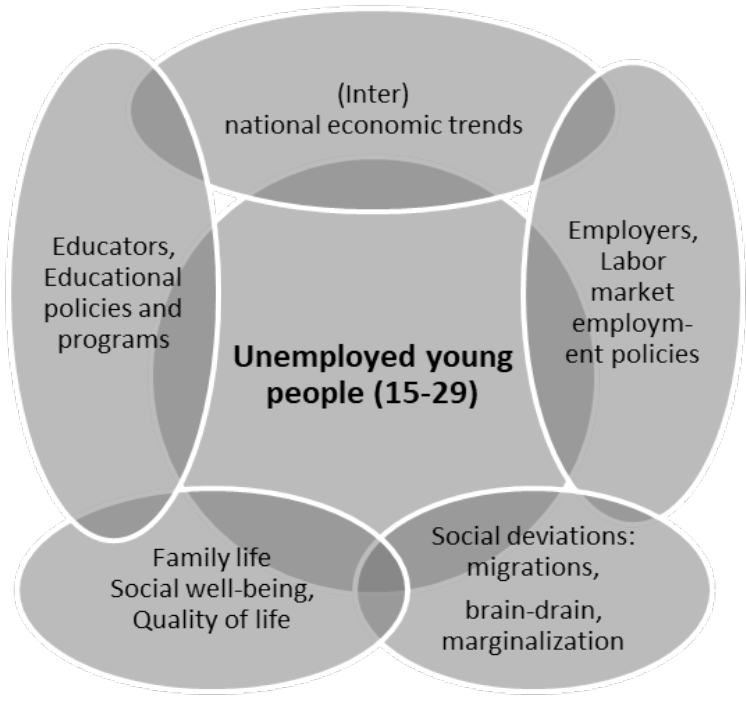

Figure 4 shows those sub-systems directly affected by youth (non)employment and in which dysfunctional changes may be observed in the long run. The social environment should be safe with a high level of trust between the newcomers to the labor market and employers. However, the

7 Due to Parson's system theory, the social system as an open and adaptable mechanism tends towards achieving a time-limited balance. The same characteristics are attributed to its structural constructs: institutions, social sectors, and subsystems (economic, political, legal-legislative, social). Altogether, these work interactively and functionally to achieve common goals. 
educational, social, and work environments in several EU countries generally do not guarantee such basic conditions that allow appropriate youth employment and indirectly safe exits from schooling to employment (Podmenik, Ivančič 2017). Sociological debates largely consider the educational sub-systems independently of how they intertwine with the others.

The changes occurring in youth labor markets have already been mentioned. They have gradually transformed from signaling and balancing to become flexible and fluid yet they are ever more susceptible to the current needs of employers (Kramberger 1999). Due to inadequate signals from labor markets, certain education systems and programs have become increasingly self-sufficient and inefficient. The new education and employment conditions are directly linked with young people's social status and way of life, influencing their quality of life and lifestyles. Traditional definitions of a career are being replaced by a new, individualistic concept that places greater responsibility on the shoulders of young jobseekers. Individual careers should be planned in line with labor market demands, but independently of those of potential employer's as much as possible (Arthur and Rousseau 1996). The discourse has been reoriented to multiple careers, lateral (and not vertical) career shifts, lifelong individual career redesigns, ongoing individual accumulation of human capital, etc. Besides this, young highly educated jobseekers should adapt to the inappropriate, horizontal and/or vertical job mismatches.

Already the brief consideration thus far of the structural dysfunctions of social subsystems directly linked to youth unemployment suggests it is possible that structural youth unemployment trends will continue in the near future. With respect to the current deadlock in all national economies, one can also anticipate social crises that would more deeply affect young people in the labor market and in employment relations.

\subsection{Young Europeans' Personal (Dis)Satisfaction and Perception of Life} The analysis of young people's attitudes to their social environment proceeds from the assumption that youth (un)employment affects individuals themselves as well as their nearest social sub-systems, and that young people's perceptions, behaviour, values and orientations should be viewed as indicating ongoing social shifts. 
It could be argued that such a theoretical starting point is closer to Giddens' structuration theory8 than Parsons' structural functionalism, cited above. Such association is unavoidable since Parsons' attempt to develop a social theory of purposive individual action (Parsons 1937) was strongly criticised and also rejected by most sociological authors with nonfunctionalist orientations (e.g. Homans, 1958; Berger and Pullberg, 1966; Giddens 1976). Besides, as Collemann (1986) warns, empirical research has developed in the opposite direction, even at a time when functional theory was dominant: "the statistical association basis for inference of survey analysis seemed to have little natural affinity for the intentions of purposes of individuals" (ibid., 1314). Vice versa, Coleman argues that neither Parsons nor Giddens paid sufficient attention to empirical research to confirm their "grand theories" (ibid.).

While structural unemployment affects social subsystems in one's (closest) surroundings, the individual as the micro unit in society and all related processes must be taken into account. And vice versa, their perceptions, behavior, values, and orientations should be viewed as indicating ongoing social shifts. In this framework how young people view their employment, their satisfaction and evaluation of everyday life may indicate different aspects of structural unemployment.

One can assume that young people's views, values, and attitudes to work, satisfaction with life, and life perspectives change when they are unemployed for a long time. Further, a comparison of the different views and opinions held by young and older generations reveal the possibility of social deprivation of the youngest in the long term. As the third aspect worthy of being compared are the differences in opinions and values among EU countries.

Data for EU 9 countries (from the latest European Values Study database) were analyzed. A comparison of the views and values held by younger (15-29 years) and older people (30-49 years and over 50 years) regarding their happiness and satisfaction in life as well as control over their own lives is shown in Figure 5.

${ }^{8}$ From a critical point of view on Parsons and structural functionalism, Giddens introduces the so called duality of structures. He envisions an interactive relationship between structures and individuals' voluntary action; voluntary activities take place within the institutional framework that mediates them and thus it itself becomes the result of such interaction.

9 The study for this article began in 2019, therefore the United Kingdom is still counted as an EU country. Not all EU countries are included in the available EVS 2017 data. 
Figure 5: Perception of people's lives by age group ${ }^{10}$

\section{Perception of life}

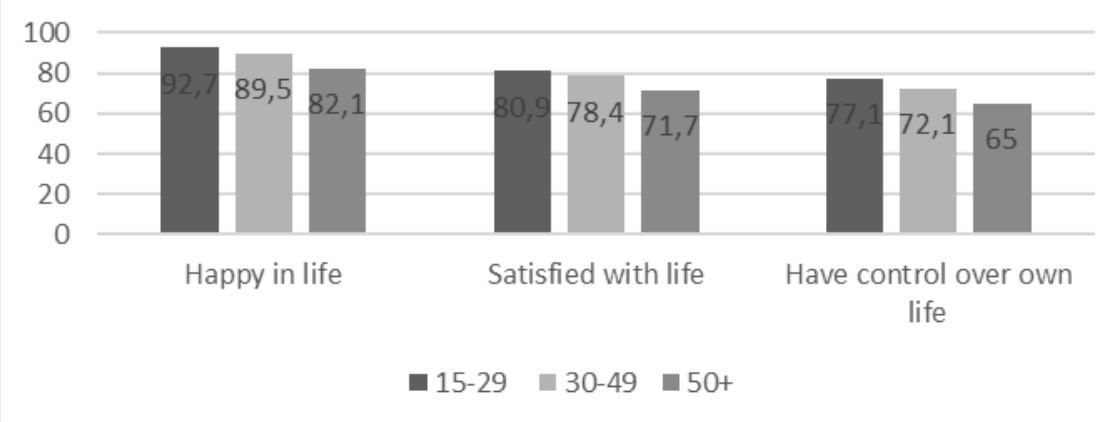

Source: European Values Survey 2017

Despite challenges when transitioning to the labor market and the higher unemployment levels, young people are still more happy and satisfied with their lives than older generations. Interestingly, they also have a greater feeling of being in control of their own lives. Majority of young people who report being very or relatively happy are from Poland, Estonia, Lithuania, Spain, and the Czech Republic, while the biggest shares of young people who report not being very happy are from Germany, Finland, and Hungary. It is interesting to note that youth in Spain, the country with the highest youth unemployment levels in Europe, report being among the happiest and most satisfied in Europe. Is it possible that, in contrast with older people, young people value work as being less important? However, it is important to mention that the average levels of life satisfaction among the younger generation rose significantly from 2008 when $70.6 \%$ of young people expressed being satisfied with their lives and $87.8 \%$ felt happy or very happy with their lives. In any case, even in 2008 the youngest generation was the happiest and most satisfied with their lives. One explanation may be that there are some differences in understanding happiness and satisfaction and the importance ascribed to the work situation within this.

Still, the vast majority of people from all generations value work as important or very important. There is only a slight difference in the youngest

10 Percentage of people noting they are happy or very happy in their lives and percentage of people who evaluated their life satisfaction and control over their own lives with numbers $7,8,9$, or 10 (on a scale 1-10 where 1 means dissatisfied/no control at all and 10 means satisfied/a great deal of control). 
group's values about work; it is (non-significantly) less important for youngest than for other age groups. This may be partly attributed to the fact that for young people leisure time, friends, and acquaintances are considerably more important than work.

The above comparisons reveal certain aspects of young people in relation to work and leisure time. It may be assumed that the young are happier than the elderly despite their higher unemployment rate and the difficulties they face in the labor market. It is reasonable to say that the perception of life held by young people differs slightly from that of older generations regarding the importance of work in their lives. Young people generally think that work is important in life, especially for developing the individual's talents, because it represents a duty to society and the notion that people who do not work become lazy. An increasing majority of young people feel that work is a human duty to society, but they do not agree that work always comes first. At the same time, they believe that reducing the importance of work would be a bad thing, again expressing a sympathetic attitude for the importance of work. They also express concern about unemployed people. Therefore, it may be summarized that the majority of young people are fond of work and believe it is important in their lives. Yet, it is interesting to observe that the share of young people who think work is very important in their lives has dropped significantly in the last 18 years.

Younger generations tend to notably disagree more than older generations with the statement that work should always come first, even if that means less spare time. They also tend to agree slightly less with the statements that work is a duty to society and people turn lazy if they do not work. It is important to see if differences also emerge in the job expectations held by younger and older generations.

Young people expect and want more in terms of accomplishing something at work, especially when compared to older age groups, which might pose a barrier for them to enter the labor market or find a job. (Too) high expectations could create an unrealistic picture that would lead to having no job completely satisfy them, hence no job is "good enough" for them. Of course, these are more extreme cases; in the authors' opinion, most young people would be willing to ignore a smaller shortfall in their expectations and accept work that does not fully meet their requirements and expectations.

There has been much discussion in recent years about younger generations' changing perspective on work, the labor market, and their attitudes to work (e.g. Twenge 2010). The perception of work being something one is passionate about, achieving something, and improving oneself influences the way young people view traditional work conditions. 
Younger generations often wish to have greater flexibility, develop their careers in several positions and companies, and not stay in just company for life. In the minds of many younger people, a 5-year contract gives the same feeling of security and accomplishment as an indefinite contract did for young people a few generations ago. The understanding of work has shifted from work as a means to survive to work as a means to find new, better-paid work (Bauman 2018). To what extent this is the result of a value change or simply adapting to alterations in the labor market remains unanswered. Berry and McDaniel (2020), on the other hand, talk about precarious work becoming "a new normality" for young people and see it as immutable, a changed economic environment where the key challenge is to navigate through it as an individual worker. It is also important to take account of the context of structural and cultural transformations that enable individuals to make reflexive deliberations about their life goals and paths, including career decisions. Whether young individuals will orient themselves well in these situations depends on several different factors like their personal characteristics, family conditions, etc. In times of educational inflation, informal education, networking and especially international mobility play a big role in an individual's success in the labor market (see Golob and Makarovič 2018). Younger generations have been growing up in the belief that higher education is the key to a better life and higher social status. Bauman (2018) states that many younger people who are highly educated think others are responsible for providing them with a good and well-paid job because they have studied for many years.

However, some important differences exist among countries. Young people's expectations of society and other external actors with regard to their expectations of life and work are not equally high across the EU. European Values Study data from 2017 show there are some important differences between countries.

When it comes to life satisfaction, people in Northern and Western Europe seem to be generally more satisfied with their lives than those in other parts of Europe. Yet, this is mainly the case among older generations. Young people in Southern and Eastern-Central Europe are slightly more satisfied with their lives than in Northern and Western Europe. The biggest difference is seen in the oldest generation, which is significantly more satisfied with their lives in the Northern and Western Europe. It is interesting to note that the highest number of young people satisfied with their lives is found in Slovenia, while the lowest numbers are in France, Sweden, and Great Britain.

It is noteworthy that in countries with higher youth unemployment levels such as Spain, Italy, and France, more young people think that work is 
important than in some other countries. For example, in the Czech Republic, a country with the lowest (youth) unemployment, there is also the biggest share of young people who think that work is not at all important in their lives. Despite life satisfaction being very high among young people in Southern Europe, the above-mentioned data indicate that youth unemployment is an important problem in young people's lives.

Other differences are seen in the perception of work. Young people in Northern and Western Europe are less likely to think that work should always come first and find good pay less important in a job compared to their peers in most countries from Southern, Eastern, and Central Europe.

We expected younger people's attitudes to their lives, life perspectives, and work to be more negative than those held by older generations and to be changing based on periods of crisis, which would serve as an additional indicator of structural unemployment in Europe. Based on the economic indicators of structural unemployment, differences between individual EU member states were also expected. The data analyzed in this chapter show that younger people do not express any sort of "crisis attitude", either compared to older generations or in a longitudinal perspective. Younger people generally seem to be happier than older people and feel more satisfied with and in control of their lives, even in times of crisis. It is, however, notable that their level of happiness and life satisfaction is higher in 2017 than it was in 2008. Compared to the older generations, young people value friends and leisure time above work. Their attitudes to work do not tend to alter based on a crisis situation, although several differences emerge among the perception of work. More and more young people perceive work as a social duty and more often than older people they want a job in which they feel like they have achieved something. As presumed, there are differences among member states, especially regarding the feeling of preparedness for the labor market, where students from countries like the Netherlands, Finland, and the Czech Republic feel significantly better prepared for the labor market than students from Slovenia, Slovakia, or Romania.

It is interesting to observe that young people in Slovenia are the most satisfied with their lives despite the persistent long-term trend in youth unemployment. One possible explanation is that other mechanisms and areas give a sense of security and life satisfaction to young people in Slovenia, who are increasingly enrolling in higher education institutions, not always to follow their academic aspirations, but in response to pressure from their parents and the environment. Such pressures are often based on the promise of a better job and life if one is well educated. A growing share of young people hold student status which brings particular social security, such as free health 
insurance, lower living costs, food vouchers, and the possibility for flexible, off-contract and low-taxed work. The housing situation adds immensely to the financial, social and material security of the young in Slovenia. Slovenia has one of the biggest shares of young adults living with their parents. Eurofound data (2017) show that $63 \%$ of people aged 25-29 live with at least one of their parents. Other countries with a high percentage of youth living at home, like Slovakia, Spain and Romania, similarly record high shares of young people who are satisfied with their lives notwithstanding they face higher youth unemployment levels.

\section{Conclusion}

By observing the long-term youth unemployment on a general level (regardless of national differences in the EU) it rises during a time of recession and poor economic growth similarly as the unemployment level for older generations and they both fall in periods of economic recovery. However, we argue that the structural nature of youth unemployment becomes obvious when during the cycle of an economic prosperity youth unemployment does not fall below the rate recorded in the previous conjuncture period, or if employment levels after the period of economic stress do not exceed those during the preceding period of economic growth. Namely, for societies longterm periods for which the paradigm of a modern knowledge society has been applied (and politically used), unemployment should be gradually declining while new jobs should be growing. This suggests that structural unemployment is indicated where both rates remain at the same level or where the level of unemployment is rising over a (very) long period of time. Observation of the available data presented in this paper shows that youth unemployment may be defined as structural, but differently with regard to three 'types' of EU member countries (that could be sampled for the needs of our investigation). ${ }^{11}$ In the group of Western and Northern, highly developed EU countries, the relatively low unemployment rates were rising in harmony during periods of crisis and falling in times of economic recovery. Yet, data for the group of Southern countries show an adaptation of unemployment to

\footnotetext{
${ }^{11}$ We again highlight the data problem in the Conclusions. Changes in data gathering and classifying methods; the negligence of some countries; the inconsistencies and inefficient control of the collectors lead to the absence of long-term consistent databases needed to analyze past and existing socio-economic conditions, and in the current pandemic, even more for urgently needed predictions.
} 
economic trends that is not in harmony: during the "2008 crisis", unemployment rates fell and even today have not returned to their post-crisis levels. The most striking results are seen in the third, Eastern - former socialist - group where unemployment rates were lowest in 2008 when the crisis was announced, but rapidly grew to become the highest in 2012 only to fall again until 2018. In addition, unemployment rates in these countries did not follow the national economic trends and were lowest in the crisis period, seeing an incomparable fall between 2012 and 2018 between theirs and those of other groups or countries. This fall may be explained as an interruption in the long-term youth unemployment of this group and thus raises doubts about the structural nature of youth unemployment, calling for further research to be conducted. But in today's circumstances of the crisis of a pandemic and with regard to the forecasts of a deep economic recession, young people will again be hit by unemployment and the re-cycling of youth structural unemployment will continue.

The present article gave multiple emphases to the problem of youth unemployment being a multidimensional subject of research. In this framework, in the final section young people's statements and values about work and life are analyzed. The starting hypothesis was that, building on the data and evidence outlined in earlier sections, young people's views on employment and life will deviate from those of the elderly in a negative direction. However, not much evidence was found about the connection between youth structural unemployment and the negative general perception of life held by young people. Younger people generally seem to be happier than older ones and feel more satisfied with and in control of their lives, even in times of crisis. However, their level of happiness and life satisfaction was higher in 2017 than it was in 2008 when the economic situation started to decline and the youth unemployment rate to rise. This suggests that unemployment still plays a big role in young people's lives and is hindering their attitudes to both their lives and their quality of life. The differences between young people's attitudes to their life and work found in different countries confirm the notion, mentioned in the introduction, that youth unemployment is a very multidimensional problem that concerns many parts of societies.

Based on both economic and sociological indicators, it is clear that young people continue to be one of the most vulnerable groups during economic crisis. While their situation in society and the labor market has improved in the last few years, they have less reason for optimism today. The global Covid19 pandemic that froze economies all over the world heralds an economic crisis that will definitely impact youth unemployment again. However, given 
the current state of the pandemic in the EU, which is still expanding, one cannot predict the severity of the anticipated (national and EU) economic and social crisis and which dimensions will be most impacted.

\section{References}

Adam, Frane. 2013. Na razpotju družbene krize. On the Cross Road of Societal Crises. Quo vadis Slovenija? Ljubljana: IRSA.

Bauman, Zygmund, and Thomas Leoncini. 2018. Born Liquid. Translated by Vasja Bratina: Tekoča Generacija, spremembe v tretjem tisočletju. Ljubljana: Založba družina.

Becker, Gary, S. 1962. "Investment in Human Capital." Journal of Political Economy 70:9-49.

Bell, Daniel. 1972, The Coming of Post-industrial Society. New York: Basic Books .

Berger, Peter, and Stanly Pullberg. 1966. "Reification and the sociological critique of consciousness." New Left Review 35 (1-2): 56-71.

Berry, Craig, and Sean McDaniel. 2012. "Post-crisis precarity: Understanding attitudes to work and industrial relations among young people in the UK." Economic and Industrial Democracy :1-22.

Boltanski, Luc and Eve, Chiapello. 2007. The New Spirit of Capitalism. London, New York: Verso.

Brauns, Hildegrad, Markus Gangl and Stegani Scherer. 2001. "Education and Employment: Patterns of labour market Entry in France, the UK and West Germany." Working Paper, University of Mannheim: Mannheim Centre for European Social Research (MZES).

Coleman, James, S. 1986. "Sociological Theory, Social Research, and a Theory of Action.” The American Journal of Sociology 91 (6): 1309-1335.

Coleman, James, S. 1991. "Matching Process in the Labour Market." Acta sociologica 34(1): 3-12. 
Dragoš, Srečo. 2020. "Socialno je politično - socialni status študentske mladine." To be published.

Eurofund. 2020. https://www.eurofound.europa.eu/news/newsarticles/data-show-proportions-of-young-people-still-living-at-home. Accessed 20.5.2020.

Eurostat Database. 2020. https://ec.europa.eu/eurostat/data/database. Accessed 5.4.2020.

Freeman, Richard, B. 1976. The Overeducated American. New York: Academic Press.

Giddens, Anthony. 1976. "Functionalism; Apres la lutte." Social research, On Marx 43 (2): 325-366.

Gesis Online Study Catalogue, European Values Survey. 2017. ://zacat.gesis.org/webview/. Accessed 5.4.2020.

Greenwood, Ian and Mark Stuart.2003. "Employability or Lifelong Flexibility: Unpicking the Contradictions of the European Employment Strategy." Paper, Leeds University, Business School.

Goldthorpe, John, H. 1996. "Problems of 'Meritocracy'." In Can Education Be Equalized? The Swedish Case in Comparative Perspective, edited by Robert Erikson and Jan Jonsson, Oxford: West View Press.

Golob, Tea, and Matej Makarovič. 2018. "Student mobility and transnational social ties as factors of reflexivity." Social sciences 7: 1-18.

Lesche, Janine, and Andrew Watt. 2010. "Labour Market Impacts of the Global Economic Crisis and Policy Responses in Europe." European Social Watch Report for Action: Responding to Poverty, Social Exclusion and Inequality in Europe and Beyond. European Trade Union Institute.

Hannan, Damian, F., and Patrick Werquin. 2001. "Education and Labour Market Change: The Dynamics of Education to Work Transitions in Europe." In Training in Europe. Second report on vocational training research in Europe 2000: background report, edited by Pascaline Descy and Manfred Tessaring, 91-135. Luxembourg: Office for Official Publications of the European 


\section{Communities.}

Homans, George. 1985. "Social Behaviour as Exchange." American Journal of Sociology 63: 597-606.

Jonsson, Janne. 1987. "Educational Resources." In Welfare in transition. A Survey of Living Conditions in Sweden 1968-1981, edited by Robert Erikson and Rune Aberg, 154-180. Oxford: Clarendon Press.

Klajnšek, Rudi, and Žiga Kobše. 2019. “Zaposlovanje”. In Slovenska mladina 2018/2019 edited by Andrej Naterer et al., 77-90. Zagreb: Friderich-EbertStiftung.

Kramberger, Anton. 1999. Poklici, trg dela in politika. Ljubljana: Fakulteta za družbene vede.

Leuven, Edwin, and Oosterbeek, Hessel. 2011. "Overeducation and Mismatch in the Labour Market." Discussion Paper Series 2523. Institute for the Study of Labour 1-53.

Mocan, Naci. 1999. "Structural Unemployment, Cyclical Unemployment and Income Inequality." The Review of Economics and Statistics 81 (1): 122-134.

Noelke, Clemens, and Walter Mueller. 2011. "Social Transformation and Education Systems in Central and Eastern Europe." In Making the Transition. Education and Labour Market Entry in Central and Eastern Europe, edited by Clemens Noelke and Michael Gebel. Stanford: Stanford University Press.

OECD. 1977. Entry of Young People into Working Life. Paris: OECD.

OECD. 1994. Vocational Education and Training for Youth - Toward Coherent Policy and Practice. Paris: OECD.

OECD. 2000. The Creative Society of the $21^{\text {st }}$ Century. Future studies. Paris: OECD.

Parsons, Talcott. 1937. The Structure of Social Action. New York: McHraw-Hill.

Parsons, Talcott. 1977. Social System and Evolution of Action Theory. New York, London: Free Press. 
Podmenik, Darka. 2013. Diplomanti v času družbene krize. Kako do ustrezne zaposlitve? Ljubljana: IRSA.

Podmenik, Darka, and Angelca, Ivančič. 2017. "Managing Human Capital and Knowledge Transfer: Dysfunctions of Youth Education and Employment." In Slovenia. Social, Economic and Environmental Issues, edited by Frane Adam. New York: NOVA Publishers.

Singh, Ruchi. 2010. "European Crisis and Its Impact on Labour Market and Unemployment in Europe - Lessons for India." Dissertation Report, Bombay: Department of Humanities and Social Sciences, Indian Institute of Technology.

Slovenian Statistical office. 2020. https://pxweb.stat.si/sistat. Accessed 27.3.2020.

Sprangers, Maarten. 1992. “Explaining Unemployment Duration." An Integrative Approach. Dissertation, University Utrecht.

Stehr, Nico. 2005. Knowledge Politics: Governing the Consequences of Science and Sozialphilosophie. Boulder, CO: Paradigm Publishers.

Teichler, Ulrich. 2007. Higher Education Systems. Conceptual Frameworks, Comparative Perspectives, Empirical Findings. Rotterdam, Taipei: Sense Publishers.

Teichler, Ulrich. 2011. "Bologna - Motor or Stumbling Block for the Mobility and Employability of Graduates?" Employability and Mobility of Bachelor Graduates in Europe. Key Results of the Bologna Process, edited by Harald Schomburg and Ulrich Teichler, 3-41. Rotterdam: Sense Publishers.

Twenge, Jean, M. 2010. "A review of the Empirical Evidence on Generational Differences in Work Attitudes." Journal of Business and Psychology 25: 201210.

Valletta, Rob, and Katherine, Kuang. 2020. "Is Structural Unemployment on the Rise?" FRBSF Economic Letter, 34. 